\title{
Dye-sensitized Photooxidation of Neutral Protease from Bacillus subtilis var. amylosacchariticus: Assignment of Histidine Residue Oxidized
}

\author{
Shin-ya Morikawa, Akio Kanatani, Tadashi Yoshimoto \\ and Daisuke Tsuru
}

School of Pharmaceutical Sciences, Nagasaki University, Bunkyo-machi 1-14, Nagasaki 852, Japan

Received Februay 14, 1991

\begin{abstract}
The neutral protease of Bacillus subtilis var. amylosacchariticus was photooxidized in the presence of methylene blue, by which treatment the enzyme was rapidly inactivated. The inactive enzyme was digested with endoproteinase Asp-N, the resultant peptides were separated by HPLC, and their amino acid sequences were compared with those obtained from the unmodified enzyme. Of four peptides that contained histidine residues, only the recovery of one peptide was found to be decreased by the photooxidation with the appearance of a new peptide. Comparisons of amino acid compositions and sequences between these two peptides showed that the latter peptide lacked His ${ }^{228}$ of the former one, indicating that $\mathrm{His}^{228}$ was photooxidized. This result suggests that $\mathrm{His}^{228}$ is involved in the catalytic reaction of the neutral protease or interaction with substrates.
\end{abstract}

Bacillus subtilis var. amylosacchariticus ( $B$. amylosacchariticus) produces a $\mathrm{Zn}$-containing neutral endopeptidase of high specific activity. ${ }^{1-4)}$ Recently, its amino acid sequence ${ }^{5)}$ and the nucleotide sequence of the enzyme gene ${ }^{6)}$ were analyzed in our laboratory. Comparison of the amino acid sequence with those of other Bacillus neutral proteases showed that the $B$. amylosacchariticus enzyme is $89 \%$ homologous to that from $B$. amyloliquefaciens and $48 \%$ homologous to thermolysin, a thermostable $\mathrm{Zn}$-containing endopeptidase from $B$. thermoproteolyticus. The putative active site amino acid residues, $\mathrm{Zn}$-binding ligands, and two $\mathrm{Ca}$ binding sites were well conserved among these proteases, as judged by comparison with those of thermolysin. ${ }^{7-11}$ )

In a previous paper, we reported that $B$. amylosacchariticus neutral protease was quite sensitive to photooxidation catalyzed by methylene blue (MB). ${ }^{12)}$ Amino acid analysis indicated that one histidine residue was oxidized with the concomitant loss of the enzyme activity. Thus, we attempted to identify the histidine residue photooxidized. This paper deals with the separation of the peptide containing the modified residue and its assignment in the primary structure of $B$. amylosacchariticus neutral protease.

\section{Materials and Methods}

Materials. Methylene blue and other sequencing grade chemicals were purchased from Nacalai Tesque, Kyoto, and endoproteinase Asp-N of a Pseudomonas fragi mutant was from Boehringer Mannheim, Germany. Phenylisothiocyanate was from Pierce, U.S.A. N-blocked synthetic peptides were obtained from the Peptide Institute, Minoh. HPLC grade acetonitrile and 2-propanol were from Kishida Chemicals, Osaka. The neutral protease was purified as described previously ${ }^{1)}$ with some modifications. ${ }^{5)}$

Assays of proteolytic activity and protein concentration. The caseinolytic activity was assayed by the method described previously, ${ }^{1)}$ and protein concentration was estimated spectrophotometrically by assuming that $E_{1 \%, 1 \mathrm{~cm}}$ at $280 \mathrm{~nm}$ was $13.8 .^{1)}$ The hydrolytic activity toward synthetic peptides was monitored by measuring the digestion products by HPLC using a Vydac Cl8 column $(5 \mu \mathrm{m}, 300 \AA, 4.6 \times 250 \mathrm{~mm}){ }^{13)}$ A linear gradient system

Abbreviations: HPLC, high performance liquid chromatography; MB, methylene blue; TFA, trifluoroacetic acid; Z-Gly-Leu- $\mathrm{NH}_{2}, \mathrm{~N}$-benzyloxycarbonyl-glycyl-L-leucine amide. 
of $0.075 \%$ TFA in water vs. $0.06 \%$ TFA in acetonitrile-2propanol $(3: 1)$ was used at room temperature and at a flow rate of $1 \mathrm{ml} / \mathrm{min}$.

Photooxidation of neutral protease. The enzyme, $2 \mathrm{mg}$, was dissolved in $2 \mathrm{ml}$ of $0.1 \mathrm{M}$ Tris- $\mathrm{HCl}$ buffer $(\mathrm{pH} 7.5)$ containing $2 \mathrm{~mm}$ calcium acetate and $0.01 \% \mathrm{MB}$ in a quart $z$ cell of $1-\mathrm{cm}$ path length. The reaction mixture was placed at distance of $20 \mathrm{~cm}$ from the front lens of a $300-\mathrm{W}$ slide projector and illuminated for 25 to $120 \mathrm{~min}$, stirred solwly to supply oxygen. ${ }^{12,14)}$ The reaction mixtures were periodically withdrawn and their proteolytic activities were checked. The remainders were mixed with $1 / 10$ volume of $99 \%$ formic acid to inactivate the remaining activity and dialyzed against $0.1 \mathrm{M}$ ammonium bicarbonate buffer $(\mathrm{pH}$ 8.0) to remove $\mathrm{MB}$.

Enzymatic digestion of the intact and oxidized enzymes and separation of the resultant peptides. The intact and photooxidized enzymes (about $1.6 \mathrm{mg}$ ) were digested with endoproteinase Asp-N for $24 \mathrm{hr}$ at $37^{\circ} \mathrm{C}$ and $\mathrm{pH} 8.0 \mathrm{in}$ a total volume of $2 \mathrm{ml}$. The ratio of enzyme to substrate was $1 / 2000(\mathrm{wt} / \mathrm{wt}$ ). Urea, $250 \mathrm{mg}$, was added to a part $(500 \mu \mathrm{l})$ of the reaction mixture to completely dissolve insoluble peptides, and then the peptides were separated by reversed-phase HPLC in a manner similar to that used for separation of digestion products from the synthetic substrates as above. Some fractions were further purified on a TSK-gel ODS $120 \mathrm{~T}$ column $(5 \mu \mathrm{m}, 120 \AA$, $4.6 \times 250 \mathrm{~mm}$ ) using the above solvent system.

Analyses of amino acid sequence and composition. Amino acids of peptides were sequenced by manual Edman degradation. ${ }^{157}$ Phenylthiohydantoin (PTH) amino acids were measured by HPLC as described by Kobayashi and Tarr. ${ }^{15)}$ Amino acid composition of peptides was determined according to Spackmann et al., ${ }^{16}$ after hydrolysis with $6 \mathrm{~N} \mathrm{HCl}$ containing a trace of phenol in vacuo at $150^{\circ} \mathrm{C}$ for $1 \mathrm{hr}$.

\section{Results and Discussion}

Photooxidation of the neutral protease and reduction of the activity

By photooxidation of the enzyme for $25 \mathrm{~min}$

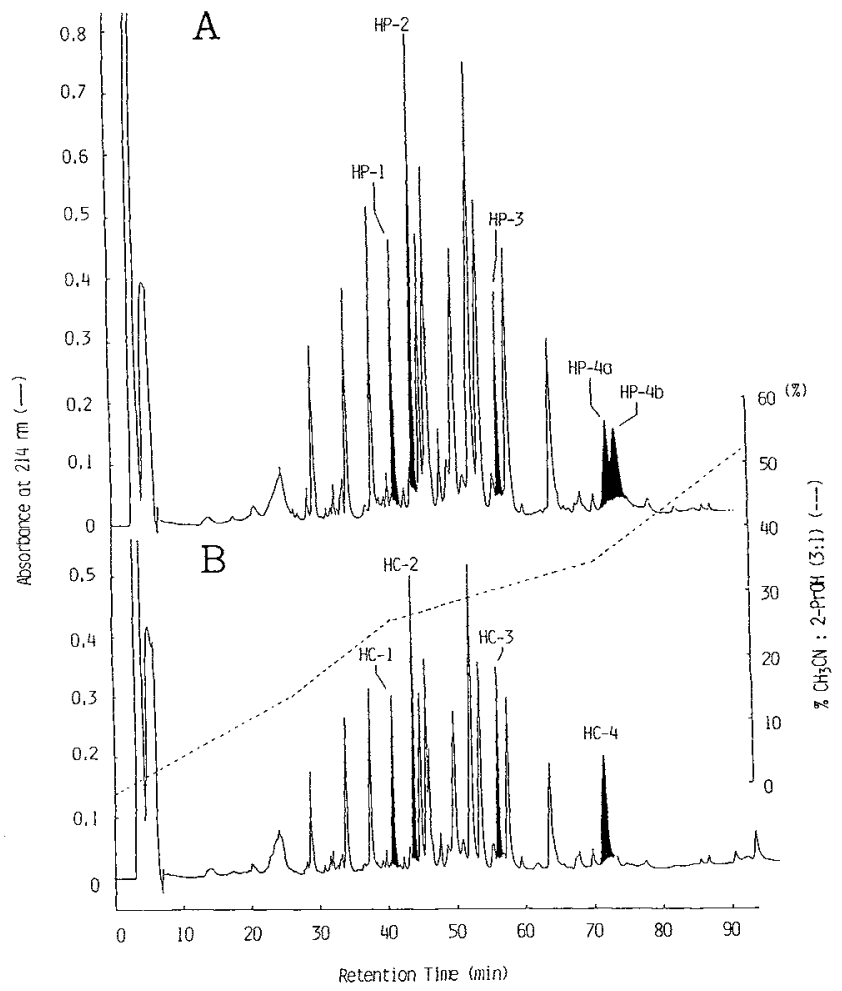

Fig. 1. HPLC Profiles of Endoproteinase Asp-N Digests of the Neutral Protease Photooxidized for $25 \mathrm{~min}$ and the Native Enzyme.

Black peaks indicate histidine-containing peptides. See the text for experimental detail.

A, modified enzyme (about $400 \mu \mathrm{g}$ ); B, intact enzyme (about $300 \mu \mathrm{g}$ ). 
Table I. Amino Acid Sequences of Amino Terminal Regions of His-containing Peptides Obtained by Endoproteinase Asp-N Digestion of the Native and Photooxidized Enzymes*

\begin{tabular}{|c|c|c|}
\hline Peak & Amino acid sequence and residue number & Yield $(\%)$ \\
\hline $\mathrm{HC}-\mathrm{I}^{* *}$ & Asp-Ala-(I) & 32 \\
\hline HP-I & Asp-Ala-WS-Tyr-Asn-Leu-Gly-Lys-Val-Tyr--- & 28 \\
\hline $\mathrm{HC}-2$ & $\begin{array}{l}95 \\
\text { Asp-Asn-Lys-Gly-Ser-Lys-Ile-Val-Ser-Ser-Val-WW-Tyr-- }\end{array}$ & 30 \\
\hline HP-2 & $\begin{array}{l}95 \\
\text { Asp-Asn-Lys-Gly-Ser-Lys-Ile-Val-Ser-Ser-Val-Wis-Tyr--- }\end{array}$ & 24 \\
\hline $\mathrm{HC}-3$ & 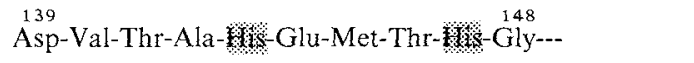 & 18 \\
\hline $\mathrm{HP}-3$ & $\begin{array}{l}139 \\
\text { Asp-Val-Thr-Ala-WG-Glu-Met-Thr-MK-Gly--. }\end{array}$ & 21 \\
\hline $\mathrm{HC}-4$ & $\begin{array}{l}223 \\
\text { Asp-Tyr-Gly-Gly-Val-1Ifs-Thr-Asn--- }\end{array}$ & 28 \\
\hline $\mathrm{HP}-4 \mathrm{a}$ & $\begin{array}{l}223 \\
\text { Asp-Tyr-Gly-Gly-Val-10 }\end{array}$ & 17 \\
\hline $\mathrm{HP}-4 \mathrm{~b}$ & Asp-Tyr-Gly-Gly-Val- $22-$-Thr-Asn--- & 21 \\
\hline
\end{tabular}

Table II. Amino ACid COMPositions of PEPTides HC-4, HP-4a AND HP-4b

\begin{tabular}{|c|c|c|c|}
\hline $\begin{array}{l}\text { Amino } \\
\text { acids }\end{array}$ & $\mathrm{HC}-4$ & $\begin{array}{c}\text { Peptides } \\
\text { HP- } 4 a\end{array}$ & $\mathrm{HP}-4 \mathrm{~b}$ \\
\hline Asx (4) & 3.5 & 4.2 & 3.6 \\
\hline Glx (2) & 2.3 & 2.6 & 2.5 \\
\hline Ser (5) & 4.7 & 4.4 & 4.4 \\
\hline Gly (4) & 4.0 & 4.3 & 4.2 \\
\hline m/ $/$ \% & $\%$ & 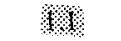 & \% \\
\hline Arg (1) & 0.9 & 1.2 & 0.9 \\
\hline Thr (7) & 6.5 & 7.0 & 6.7 \\
\hline Ala (3) & 3.4 & 3.5 & 3.3 \\
\hline Pro (2) & 1.8 & 1.7 & 2.3 \\
\hline Tyr (5) & 5.0 & 4.8 & 5.5 \\
\hline Val (2) & 1.5 & 1.4 & 1.4 \\
\hline \multicolumn{4}{|l|}{ Met $(0)$} \\
\hline \multicolumn{4}{|l|}{ Cys (0) } \\
\hline Ile (3) & 2.7 & 2.5 & 3.0 \\
\hline Leu (3) & 2.7 & 3.2 & 3.3 \\
\hline Phe (I) & 1.0 & 1.0 & 0.9 \\
\hline Lys (4) & 3.5 & 4.3 & 4.4 \\
\hline $\operatorname{Trp}(0)$ & & & \\
\hline
\end{tabular}

Residue No.

$223-269$

The number in parenthesis indicates the composition ( $\mathrm{mol} / \mathrm{mol}$ ) expected from the amino acid sequence.

under the condition described in Materials and Methods, the caseinolytic activity was reduced to less than $30 \%$ of the initial activity. In the
90 min photooxidation, the enzyme activity was almost completely lost. The hydrolytic activity toward synthetic substrate, Z-Gly-Leu$\mathrm{NH}_{2}$, was also reduced parallelly to the caseinolytic activity. Amino acid analysis indicated that loss in the activity is closely related to the modification of one histidine residue.

Digestion of the modified enzyme with endoproteinase Asp- $N$ and identification of the histidine residue photooxidized.

An HPLC elution profile of endoproteinase Asp- $\mathrm{N}$ digests of the neutral protease modified by $25 \mathrm{~min}$-photooxidation is illustrated and compared with that from the intact protein in Fig. 1. Of 16 main peaks derived from the native enzyme, four peptides (black peaks in Fig. 1) contain histidine residues, as has been reported previously. ${ }^{5)}$ One of them, peak HC-4 (HP-4a in the modified enzyme) was decreased by the photooxidation, and a concomitant increase in a new peak (HP-4b) was observed.

Amino acid sequences of amino terminal regions of His-containing peptides are shown in Table $\mathrm{I}$, and amino acid compositions of three peptides, HC-4, HP-4a, and HP-4b, are shown in Table II, Peak HC-4 obtained from 


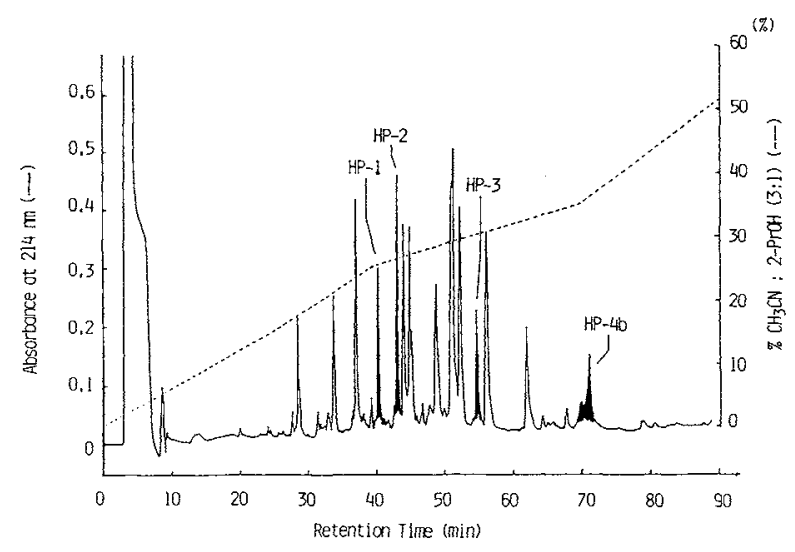

Fig. 2. HPLC Profile of Endoproteinase Asp-N Digests of the Neutral Protease Photooxidized for $90 \mathrm{~min}$. Black peaks indicate histidine-containing peptides. See the text for experimental detail.

the native enzyme was found to correspond to the peptide of residue Nos. 223-269, and decreased by the photooxidation, accompanied by the activity loss of the enzyme. The amino acid sequence and composition of a new peptide, HP-4b, were identical to those of HC-4, except that the former peptide lacked a histidine residue. These results strongly suggest that $\mathrm{His}^{228}$ is closely related to the hydrolytic reaction of the enzyme. There is, however, some discrepancy between the degree of enzyme inactivation and a relative ratio of $\mathrm{HP}-4 \mathrm{~b}$ to HP-4a; inactivation percentage of the enzyme is somewhat higher than the accumulation degree of HP-4b. This is presumably due to a further change of HP-4b to an unknown product during the photooxidation reaction, as shown later.

An HPLC elution profile of the enzymatic digests of the neutral protease modified by 90-min photooxidation is illustrated in Fig. 2. A further decrease in peak HP-4a and concomitant increase in peak HP-4b were observed, though the recovery of the latter peak was significantly lower than that we expected. Unfortunately, we could not identify the photooxidation-derived product from histidine. In addition, further elongation of illumination time caused both peptides, HC-4 (HP-4a) and HP-4b to vanish, suggesting that further destruction or conversion of HP-4b to another unknown product took place.
Taking into account a high homology in amino acid sequences between thermolysin and B. amylosacchariticus neutral protease and the three dimensional structure of the former enzyme, ${ }^{8-11,17)}$ we conclude that $\mathrm{His}^{228}$ of this enzyme corresponds to $\mathrm{His}^{231}$ of thermolysin and is involved in the catalytic reaction or substrate-binding of the enzyme.

To elucidate more detailed structure in active sites of the neutral protease, analysis by site-directed mutagenesis and a computermodelling of the three dimensional structure are now in progress.

Acknowledgment. We are grateful to Dr. R. Kobayashi for his valuable advice in amino acid sequence analysis.

\section{References}

1) D. Tsuru, T. Yamamoto and J. Fukumoto, Agric. Biol. Chem., 30, 651 (1966).

2) D. Tsuru, H. Kira, T. Yamanoto and J. Fukumoto, Agric. Biol. Chem., 30, 856 (1966).

3) D. Tsuru, H. Kira, T. Yamamoto and J. Fukumoto, Agric. Biol. Chem., 30, 164 (1966).

4) D. Tsuru, T. Yoshimoto, T. Yoshida and J. Fukumoto, Int. J. Prot. Res., 2, 75 (1970).

5) R. Kobayashi, T. Yoshimoto and D. Tsuru, Agric. Biol. Chem., 53, 2737 (1989).

6) T. Yoshimoto, H. Oyama, T. Takeshita, H. Higashi, S. Xu and D. Tsuru, J. Ferment. Bioeng., 70, 370 (1990).

7) K. Titani, M. A. Hermodson, L. H. Ericson, K. A. Walsh and H. Neurath, Nature, New Biol., 238, 35 (1972). 
8) P. M. Colman, J. N. Jansonius and B. W. Matthews, J. Mol. Biol., 70, 701 (1972).

9) A. F. Monzingo and B. W. Matthews, Biochemistry, 23, 5724 (1984).

10) D. G. Hangauer, A. F. Monzingo and B. W. Matthews, Biochemistry, 23, 5730 (1984).

11) H. M. Holden, D. E. Tronrud, A. F. Monzingo, L. H. Weaver and B. W. Matthews, Biochemistry, 26, 8542 (1987)

12) D. Tsuru, T. Hirose and J. Fukumoto, J. Biochem., 70, 699 (1971).
13) R. Kobayashi, A. Kanatani, T. Yoshimoto and D. Tsuru, J. Biochem., 106, 1110 (1989).

14) N. Tudball and P. Thomas, Biochem. J., 123, 421 (1971).

15) R. Kobayashi and G. E. Tarr, Proteins, Nucleic Acids and Enzymes (in Japanese), 31, 991 (1986).

16) D. H. Spackman, W. H. Stein and S. Moore, Anal. Chem., 30, 1190 (1958).

17) B. W. Matthews, J. N. Jansonius, P. M. Colman, B. P. Schoenborn and D. Dupourque, Nature, New Biol, 238, 37 (1972). 